\title{
LIMITATIONS ON JURISDICTION AND ARBITRATION AGREEMENTS BASED ON APPLICABLE LAW AND THE IDENTITY OF THE CARRIER IN CARGO CLAIM DISPUTES: WHO AND WHERE TO SUE?
}

\author{
LAS LIMITACIONES A LA AUTONOMÍA LA VOLUNTAD \\ DE LAS PARTES EN LAS CLÁUSULAS ATRIBUTIVAS \\ DE JURISDICCIÓN Y LAS CLÁUSULAS DE ARBITRAJE \\ BASADAS EN LA LEY APLICABLE Y LA IDENTIDAD DEL \\ TRANSPORTISTA EN LAS RECLAMACIONES POR PÉRDIDA \\ O DAÑOS A LAS MERCANCÍAS: ¿A QUIÉN Y DÓNDE SE \\ PUEDE RECLAMAR?
}

\author{
JONATAN ECHEBARRÍA FERNÁNDEZ \\ Ph.D. candidate, CBS Law, Copenhagen Business School \\ University College Dublin (UCD) Sutherland Doctoral Fellow
}

Recibido: 10.12.2018 / Aceptado: 16.01.2019

DOI: https://doi.org/10.20318/cdt.2019.4621

\begin{abstract}
The article demonstrates through an analysis of the limitations on choice of forum or arbitration agreements following the declaration of invalidity of a choice of law clause included in a charter party and/or a bill of lading $(\mathrm{B} / \mathrm{L})$ by a judge. It is equally difficult enforcing a jurisdiction or arbitration clause included in a $\mathrm{B} / \mathrm{L}$ if the parties are not clearly defined in the contract for the carrige of goods by sea. The article delivers some conclusions and suggests the approach to be taken by maritime contracting parties to overcome any feasible invalidity of a choice of forum or arbitration agreement based on the choice of law by European Member (EU) States' courts.

Keywords: Jurisdiction and arbitration agreements, choice of law clauses, contracts for the carriage of goods by sea, charter party, bill of lading, anti-suit injunctions, actions in contract, actions in tort, actions in bailment, Demise Clause, Identity of the Carrier Clause.

Resumen: El artículo demuestra a través de un análisis de las limitaciones en la elección del foro o los acuerdos de arbitraje tras la declaración de invalidez de una cláusula de elección de ley por parte de un tribunal incluida en un conocimiento de embarque y/o conocimiento de embarque $(B / L)$ por parte de un juez. Es igualmente difícil hacer cumplir una cláusula de jurisdicción o arbitraje incluida en un B/L si las partes no están claramente definidas en el contrato para el transporte de mercancías por mar. $\mathrm{El}$ artículo presenta algunas conclusiones y sugiere el enfoque que deben adoptar las partes contratantes marítimas para superar cualquier posible invalidez de un acuerdo de elección de foro o arbitraje basado en una elección de la ley por los tribunales de Estados miembros de la Unión Europea (UE).

Palabras clave: Cláusulas de elección de foro y acuerdos de arbitraje, cláusulas de elección de ley, contratos para el transporte de mercancías por vía marítima, fletamento, conocimiento de embarque, medidas antiproceso, acciones contractuales, acciones extracontractuales, acciones basadas en "bailment", cláusula de cesión, cláusula de identidad del transportista.
\end{abstract}


Sumary: I. Party autonomy. 1. Introduction. 2. Procedural party autonomy. 3. Party autonomy in conflict of contract laws. 4. Material or substantive party autonomy. II. A particular note on maritime arbitration and applicable law. 1. Party autonomy and maritime arbitration. 2. Determination of the applicable law by the arbitral tribunal. III. Direct actions and the compulsoriness for third party claimants of a dispute resolution and choice of law clauses in an insurance contract. 1. ExtraEuropean Union proceedings. 2. Intra-European Union proceedings. IV. Limitations on choice of forum and arbitration agreemements based on the the identity of the shipping carrier. 1. Introduction. 2. General rules in defining responsibilities. 3. The identity of the charterer and the shipper under Scandinavian law. 4. Comparative case law on the limitations on dispute resolution agreements based on the identity of the carrier. A) England. B) Spain. C) Germany. V. Conclusions.

\section{Party autonomy}

\section{Introduction}

1. Party autonomy plays an important role in the international carriage of goods but requires a focus on procedural party autonomy rather than material one based on characterisation of dispute resolution clauses and shipping contracts. The same contractual reality is addressed differently in various legal frameworks, in which rules of applicability may include express or implied submission to a court or arbitral tribunal, the double effect of the choice of forum clause (derogatio fori and prorogatio fori), interaction between forum and ius, substantive and formal conditions for validity of arbitration agreements, connections between litigation and the chosen court, conclusions to agreements before or after a cargo claim, enforceability vis-à-vis third party cargo claimants not party to the agreement and the characterisation of a competent forum or arbitral seat arising from party autonomy.

2. The non-recognition of arbitration and jurisdiction clauses by courts or the arrest of ships occur when the level of party autonomy generates asynchronies. Party autonomy whether procedural, substantial or in conflict of contract laws is asymmetrically developed at European and international level. This is a proof of the lack of harmonisation of procedural, material and conflictual rules. There are no mechanisms that provide unification and harmonisation within conventional, EU or domestic legal frameworks. There is a trend towards 'diversification, specialisation and flexibility' in conflict of laws rules of international or European instruments (such as the Rome I and Rome II Regulations) ${ }^{1}$ in order to determine the most appropriate substantive law according to the conflict of laws rules that encompass the objectives of legislative policy of each forum. ${ }^{2}$

3. The Brussels I Recast Regulation, following its predecessor, ${ }^{3}$ enhances the free circulation of judgments according to Recital 27: "a judgment given in a Member State should be recognised and enforced in another Member State even if it is given against a person not domiciled in a Member State". The exequatur or declaration of enforceability is not required but a single form filled out by the EU Member State court rendenging the judicial decision to be enforced in another EU Member State (Article 39). Provisional, including protective measures are enforceable in another EU Member State court according to Article 42.

4. Moreover, the Rome I Regulation provides legal security and a uniform application of the law to the contract while enhancing the free movement of judgments between EU Member States. According to Recital 6 of the Rome I and Rome II Regulations:

\footnotetext{
1 Regulation (EC) No 864/2007 of the European Parliament and of the Council of 11 July 2007 on the law applicable to non-contractual obligations (Rome II) OJ 2007 L 199/40 (Rome II Regulation).

2 J. D. González Campos, Diversification, Spécialisation, Flexibilisation et Matérialisation des Règles de Droit International Privé: Cours General, Martinus Nijhoff, 2002.

3 Council Regulation (EC) No 44/2001 of 22 December 2000 on jurisdiction and the recognition and enforcement of judgments in civil and commercial matters OJ L 012/1. The Heidelberg report details explanatory notes: B. Hess, T. PfeIfFER and P. Schlosser, Report on the Application of Regulation Brussels I in the Member States ('Heidelberg Report') [2008], Study JLS/ $\mathrm{C} 4 / 2005 / 03$.
} 
"The proper functioning of the internal market creates a need, in order to improve the predictability of the outcome of litigation, certainty as to the law applicable and the free movement of judgments, for the conflict-of-law rules in the Member States to designate the same national law irrespective of the country of the court in which an action is brought".

5. This author considers procedural law to be reasonably well ranked, and the intention is to prove this throughout this article. Nevertheless, the law is not perfect. Recognition and enforcement of jurisdiction and arbitral awards are not analysed in this article since they constitute a separate and singular issue.

\section{Procedural party autonomy}

6. There are three selected realities on international freight transport: procedural autonomy, excluding recognition and enforcement (principle of specialty), which has advanced much more in all sectors; party autonomy in conflict of contract laws, that is, conflicts of interest (the model of Rome I and Rome II Regulations shall be followed by an EU court but outside the EU, judges apply its conflict norm) and finally, international commercial matters, that is, material party autonomy (i.e. contractual clauses). There is no single convention at the EU level on this issue. Consequently, this leads to territorial sectoralisation where every judge applies its own law. Is this a reasonable mechanism to harmonise solutions and provide legal certainty? Certainly does not. Does EU law provide a scope to this material party autonomy? It provides a uniform response to the conflictual but not the material scope. Are conventions a harmonising solution? Certainly they are not. First, it depends on whether each State ratifies them and, second, we do not have a conventional norm that regulates this question in a harmonised way. This is achieved in procedural matters.

7. By choosing different models (e.g. what is understood by 'charter party' or other concepts to be analysed), this article shows that there is a plurality of concepts due to the nationalisation of the qualification of concrete problems. The interpretation of a dispute resolution clause by a Spanish or English court will be different. Even if this perspective seems descriptive, it is selectively descriptive, adding an original viewpoint on party autonomy regarding contracts of affreightment.

8. The recognition and enforcement of choice of forum clauses by EU Member State courts are related to procedural party autonomy. Procedural party autonomy and choice of law are analysed prior to litigation, i.e. the substance of the case. Article 25(1) of the Brussels I Recast Regulation ${ }^{4}$ provides for the formal validity and the consent of the parties but not the substantive validity of the choice of forum clause that is subject to the law of the EU Member State court where enforcement is sought. The EU Member State court "seised should assess the validity of the agreement according to the "law of the Member State of the court or courts designated in the agreement, including the conflict-of-laws rules of that Member State", 5 according to Recital 20 of the Regulation. The 2005 Hague Convention on Choice of Court Agreements ${ }^{6}$ is proof of how much easier it is to reach a consensus on the delegation of sovereignty in procedural than substantive matters. ${ }^{7}$

\footnotetext{
4 Article 25 states:

"The agreement conferring jurisdiction shall be either: (a) in writing or evidenced in writing; (b) in a form which accords with practices which the parties have established between themselves; or (c) in international trade or commerce, in a form which accords with a usage of which the parties are or ought to have been aware and which in such trade or commerce is widely known to, and regularly observed by, parties to contracts of the type involved in the particular trade or commerce concerned."

5 P. Garcimartín, "Prorogation of Jurisdiction - Choice of Court Agreements and Submission (Arts. 25-26)", in DiCKINson, A., Lein, E. and James, A. (eds.), The Brussels I Regulation Recast, Oxford University Press, 2015, pp. $25-26$ (hereafter "GARCIMARTíN").

6 The Convention on Choice of Court Agreements, approved on 30 June 2005 at the 20th Session of the Hague Conference on Private International Law (entered into force on 1 October 2015), 44 ILM 1294. The Council of the EU Decision 2014/887/ EU of 4 December 2014 approved the Convention on behalf of the EU ([2014] OJ L353/5).

7 Article 5(1) of the Hague Choice of Court Convention follows the Brussels I Recast Regulation and provides for the chioce of law rules of the State concerned; in X. Kramer and E. Themel, "The Party Autonomy Paradigm: European and Glob-
} 
9. It shall be noted that some specialised conventions (including maritime related ones) to which the EU Member States are parties on jurisdiction, lis alibi pendens, and the recognition and enforcement of judgments can take precedence over the regime established by the Brussels I Recast Regulation. ${ }^{8}$ The interaction of legal frameworks in presence requires the legal operator being aware of the rule of specialty, reflected normatively in its origin in the drafting of article 57 of the 1968 Brussels Convention, ${ }^{9}$ currently included in Article 71 of the Brussels I Recast Regulation. ${ }^{10}$

10. The "hermeneutical" interpretation of the Court of Justice of the European Union (CJEU) is anchored in the compulsory presence of a series of legal conditions for the prevailing application of the special agreements over secondary EU legislation (EU Regulations). ${ }^{11}$ That doctrine, as inferred from the CJEU's case law, is based on a high degree of predictability on the outcome of a judicial procedure, a good administration of justice, a reduction of parallel proceedings, the guarantee of compliance with the principle of the free circulation of judicial resolutions in civil and commercial matters and the notion of reciprocal trust between EU Member State courts. ${ }^{12}$ The rule of specialty is not activated automatically for all special international agreements,$^{13}$ once the qualification requirements are assessed, when it contains a direct or indirect regulation of judicial competence, with full compatibility with the objectives of the EU legislation. Otherwise, the applicable EU rules on jurisdiction come into play. ${ }^{14}$

\section{Party autonomy in conflict of contract laws}

11. Arbitration and jurisdiction agreements are excluded from the scope of application of the Rome I Regulation as set out in its Article 1(2)(e) and there is no uniform conflict of laws rule to determine their validity. The EU Member States apply their domestic choice of law rules, leading to the application of their lex fori, their lex causae or a combination of both. ${ }^{15}$ A choice of a non-EU Member State court leads "to lead to the non-application of other jurisdiction rules of the Regulation, the choice should satisfy the formal requirements of Article 25(1) and not be contrary to the protective and exclusive jurisdiction as referred to in Article 25(4) Brussels I bis Regulation". ${ }^{16}$

12. Article 3(1) of the Rome I Regulation sets out the party autonomy in conflict of contract laws in the EU. The first and most efficient connecting factor to determine the 'Lex Contractus' or law applicable to the contract is the party autonomy in conflict of contract laws. It does not benefit nor create obligations to third parties (pacta tertiis nec nocent nec prosunt). ${ }^{17}$ The party autonomy in conflict of contract laws is the subjective right available to the contracting parties consisting of being able to choose

al Developments on Choice of Forum", in V. Lazić and S. Stuis (eds.), Brussels Ibis Regulation, TMC Asser Press, 2017, pp. 27-49, at pp. 40-41 (hereafter "KrAMER and THEMELI").

8 J. J. Álvarez Rubio, La dimensión procesal internacional en la Ley de navegación marítima, Anuario español de derecho internacional privado, No. 14-15 (2014-2015), pp. 159-203.

9 Vid. S. M. CARbone, Lo spazio giudiziario europeo: La Convenzioni di Bruxelles e di Lugano, Torino, G. Giappichelli Editore, 1997, pp. 11 et seq.

10 According to article 71(1), "This Regulation shall not affect any conventions to which the Member States are parties and which, in relation to particular matters, govern jurisdiction or the recognition or enforcement of judgments".

11 J. J. Álvarez Rubio, "La regla de especialidad como cauce para superar los conflictos normativos entre el Derecho comunitario y los Convenios internacionales en materias especiales", La Ley, 29 October 2010, pp. 1-6.

12 See the judgment of 19 December 2013, Nipponkoa Insurance Co (Europe) Ltd v Inter-Zuid Transport BV, C-452/12, EU:C:2013:858, and the judgment of of 4 May 2010, TNT Express Nederland BV $v$ Axa Versicherung AG, C-533/08, EU:C:2010:243.

13 On the theory of the layers of specificity and the collision between agreements, vid., ad ex. F. MAJoros, Les Conventions Internationales en matière de Droit privé. Abrégé theorique et traité pratique, vol. 1, A. Pedone, 1976, pp. 282 et seq.

14 F. Garau Sobrino, "La literalidad interpretada desde la coherencia del sistema. Las relaciones entre Reglamento Bruselas I y los convenios sobre materias particulares según el TJUE”, Cuadernos de Derecho Transnacional, vol. 3, No. 1, 2011, pp. 270-281.

15 P. A. Nielsen, “The new Brussels I regulation”, Common Market Law Rev 50(2), 2013, pp. 503-528, at p. 523.

16 Vid. P. Garcimartín (note 5), p. 281; in Kramer and Themeli (note 7), pp. 40-41.

17 Carrascosa González, J., Conflicto de leyes y teoría económica, Colex, 2011, pp. 209-211 (hereafter “CARrascosa”). 
"the law applicable to the whole or to part only of the contract" ${ }^{18}$ The contract is subject to the valid law chosen by the parties subject to the minimum conditions prescribed by the Article.

13. Other international agreements that regulate international contractual obligations also include this connection criterion ${ }^{19}$ since the entry into force of the Rome Convention. ${ }^{20}$ The reason to justify the connecting factor as the first criterion to determine the law applicable to international contracts in the Rome I Regulation is the 'preventive legal security'. The parties will be able to comply with the obligations agreed in the contract. The parties are aware, ex ante, of the applicable law to the contract without relying on the law that a judge or arbitrator will determine as applicable. The party autonomy in conflict of contract laws enhances the good administration of Justice since the judge or arbitrator are fully aware of what specific law should govern the contract, i.e. the one chosen by the parties. The choice of law allows the contracting parties to submit their legal relationship to the 'most appropriate substantive law` to their interests. ${ }^{21}$

14. The main reasons to choose a specific State law as the applicable law to the contract are the following:

(i) Companies can submit all their contracts to the same State law avoiding transaction costs through a 'standardisation' of the applicable law while benefiting from the economies of scale in drafting the contracts. ${ }^{22}$ The reasoning behind such connecting factor is clearly based on the efficiency in terms of costs of conflict. The contract has an impact on contracting parties, allowing them to choose applying the "most adequate law" to their contractual relationship according to their interests. ${ }^{23}$

(ii) Parties can choose a 'neutral' law to their interests, eg the most advantageous one that could be a the law of a State that has ratified an specific international convention; ${ }^{24}$ thus, it is common that contracts for the carriage of goods by sea are subject to English law and jurisdiction since the judge does not have the power to complete or correct the wording of contract clauses. Each contracting party prefers applying the law that they better know (i.e. their national law or the one they are familiarised with). The application of their home law reduces the information and legal advice costs. The parties prefer avoiding additional expenses for being informed about a foreign law that increases their global "cost of

18 A.-L. Calvo Caravaca and J. Carrascosa González, Derecho internacional privado, vol. II, Comares, 2016, pp. 901905 (hereafter "CALvo \& Carrascosa"); J. Carrascosa GonzÁlez, La ley aplicable a los contratos internacionales: el Reglamento Roma I, Colex, 2009, pp. 117-124 (hereafter "CARRASCOSA").

19 Vid. O. LANDO, "The conflict of laws of contracts: general principles", 189 RCADI, 1984, pp. 225-447; id., "International Encyclopedia of Comparative Law”, vol. III , Ed. Lipstein, 1976, Chapter 24'Contracts`; P. A. NIELSEN and O. LANDO, "The Rome I Regulation", 45 Common Market Law Review, 2008, p. 1687; H. BATIFFoL, "Les conflits de lois en matière de contrats: étude de droit international privé comparé", Sirey, 1938, pp. 20-25; id. "Unilatéralisme et contrats en droit international privé", Liber amicorum Adolf F Schnitzer, Librairie de l'Université de Genève, 1979, pp. 7-31; id. "Subjectivisme et objectivisme dans le droit international privé des contrats", Choix d'Articles rassemblés par ses amis, Librairie General de Droit et de Jurisprudence, 1976, pp. 249-263.

20 Convention on the law applicable to contractual obligations opened for signature in Rome on 19 June 1980 OJ 1980 L 266/1, consolidated version OJ 1998 C 27/34 (Rome Convention).

21 P. Mayer and V. Heuzé, Droit international privé, Montchrestien, 2004, pp. 515-531 (hereafter "Mayer \& HeuzÉ"); Calvo \& Carrascosa (note 18), pp. 90-905; Carrascosa (note 18), pp. 117-124.

22 D. Holleaux, J. Foyer, and G. de Geouffre de La Pradelle, Droit International Privé, Masson, 1987, pp. 592-594; M. Virgós Soriano, "Obligaciones contractuales", in J. D. González Campos et al. (eds.), Derecho internacional privado, Parte especial, 6th edn, Eurolex, 1995, 143-208; id. “Artículo 10. Apartado 5”, in M. Albaladejo and S. Diaz Alabart (eds.), Comentarios al Código civil y compilaciones forales, $2^{\text {nd }}$ edn., vol. I, Edersa, 1995, pp. 609-694.

23 Mayer \& Heuzé (note 21), p. 514; D. Bureau and H. Muir Watt, Droit international privé, Tome I Partie générale, Presses Universitaires de France, 2007, p. 534; B. Audit, "Le caractère fonctionnel de la règle de conflit (Sur la "crise" des conflits de lois)", vol. 186, Recueil des cours de Droit International, 1984, pp. 219-398, at pp. 291.

24 J.-M. JACQUET, “Contrats”, Repertoire de droit international, vol. 1, Encyclopedie Dalloz, 1998, pp. 1-50. 
conflict". ${ }^{25}$ Such choice "strives for positive economies of scale" and "does not express any evaluation that other laws are better or worse than its home law". ${ }^{26}$

(iii) The law of the country of origin or residence of the parties is their preferred one, since the additional cost to research and adapt the contract to a foreign law entails additional costs ${ }^{27}$ the contracting parties can take into consideration the "substantial content" of the applicable law promoting a "free competition between State laws" that favours the parties' interests. ${ }^{28}$ The States are, in principle, indifferent to a choice of law between the contracting parties since they have no public access to the choice of their lex fori and cannot tax it. ${ }^{29}$ However, the States have an indirect interest to increase their tax revenue from a legal industry or specialised market at a global or regional level. ${ }^{30}$

\section{Material or substantive party autonomy}

15. The EU has legislated on party autonomy in conflict of contract laws with the Rome I and Rome II Regulations in the field of contractual obligations, but not substantive party autonomy as a last resort. That is to say, the scope of material autonomy is marked not by EU Law but by conventional or domestic law. To what extent can parties agree to a limitation of liability? Is it limited by EU law? No; it is limited by the different applicable domestic laws. Material party autonomy is not regulated at the EU level, unlike the party autonomy in conflict of contract laws concerning the freedom of will to agree to attributive jurisdiction or Alternative Dispute Reoslution (ADR). The choice of law offers reasonable comfort to the parties but not concerning material party autonomy for substantively or materially negotiated contractual clauses (e.g. the right to standardised contract forms). There is also no pattern of material harmonisation for the singularisation of the contractual relationship. This creates dysfunctions in the shipping market.

16. The time-bar for cargo claims, a substantive and non-procedural issue, constitutes an example of the exercise of a non-contractual claim. There are as many answers as domestic laws. We have no global agreement and the Rotterdam ${ }^{31}$ (still not in force) or Hamburg ${ }^{32}$ Rules do not provide a solution in that respect. We also have no rule on limitation in EU Law. The Rome I Regulation only states that the law applicable to the statute of limitations is the law applicable to the contract. Then, the material scope of the conflicting choice of law arises since there is no material harmonisation on that issue.

17. The freedom of choice of law by the parties according to Article 3 of the Rome I Regulation is applicable to ad extra EU "international" contracts and ad intra EU "domestic contracts" "where all other

25 L. F. CARRILlo Pozo. El contrato internacional: la prestación característica, Real Colegio de España, 1994; id., "La ley aplicable al contrato en defecto de elección: un análisis de la jurisprudencia”, Revista del poder judicial, vol. 74, 2004, pp. 1146 (hereafter "CARRILlo"); R. WAGNER, "Der Grundsatz der Rechtswahl und des mangels Rechtswahl anwendbarer Recht (Rom I-Verordnung) Ein Bericht über die Entstehungsgeschichte und den Inhalt der Artikel 3 und 4 Rom I-Verordnung", IPRax: Praxis Des Internationalen Privat-Und Verfahrensrechts, vol. 28, 2008, no. 5, pp. 377-386.

26 P. Mankowski, “Article 3", in U. Magnus, and P. Mankowski (eds.), Rome I Regulation - Commentary, European Commentaries on Private International Law (ECPIL), Otto Schmidt, 2017, pp. 120-121 (hereafter "MANKowskI").

27 G. WAGner, "The Economics of Harmonization: the Case of Contract Law", Common Market Law Review, vol. 39 , 2002, no. 5, pp. 995-1023; CARRILLo (note 25), pp. 33-44.

28 CARAVACA \& GonZÁlez (note 18), pp. 901-905; GonZÁLEZ (note 18), pp. 117-124.

29 G. RÜHL, "Wettbewerb der Rechtsordnungen im Vertragsrecht: Wunsch und Wirklichkeit?", in W. A. KAAL, M. SCHMIDT and A. Schwartze (eds.), Festschrift zu Ehren von Christian Kirchner, Mohr Siebeck, 2014, pp. 975-993, at p. 979.

30 A. Ogus, "Competition Between National Legal Systems: A Contribution of Economic Analysis to Comparative Law", ICLQ 48, 1999, p. 405, at p. 408; id., "Economic Analysis and Comparative Law", in D'ici, d'ailleurs, harmonisation et dynamique du droit, Mélanges en l'honneur de Denis Tallon, Société de législation comparée, 1999, p. 169, at p. 172; G. RÜHL, Statut und Effizienz: ökonomische Grundlagen des internationalen Privatrechts, vol. 95, Mohr Siebeck, 2011, p. 234; in CARRASCOSA (note 17), pp. 209-211; in MANKOWSKI (note 26), pp. 120-121.

31 The 2008 Convention on Contracts for the International Carriage of Goods Wholly or Partly by Sea was adopted in New York on 11 December 2008.

32 The United Nations Convention on the Carriage of Goods by Sea ('The Hamburg Rules') approved in Hamburg, 30 March 1978 that entered into force on 1 November 1992. 
elements relevant to the situation at the time of the choice are located in one or more Member States". EU law is applicable to the latter "where appropriate as implemented by the Member State of the forum" and "cannot be derogated from by agreement" according to Article 3(4) of the Rome I Regulation.

18. The main limitations on party autonomy are based on public policy (ordre public) and the overriding mandatory rules of the forum. These are not choice of law rules. Article 9 of the Rome I Regulation (overriding mandatory provisions) "narrowed the expanse of private empowerment" by means of "provisions the respect for which is regarded as crucial by a country for safeguarding its public interests, such as its political, social or economic organisation, to such an extent that they are applicable to any situation falling within their scope, irrespective of the law otherwise applicable to the contract". Those rules may override a choice of forum or the choice of law when a court thinks this makes sense in terms of the policies they express. The multiplication of overriding mandatory rules has faded the lines between ad intra and ad extra EU contracts. Sovereign regulatory surpass national borders due to the appereance of "new forms of market regulation or the growing interconnectedness of local economies" ${ }^{33}$ In the absence of a choice of law for a jurisdiction or arbitration agreement, separately from the law applicable to the charter party or the $\mathrm{B} / \mathrm{L}$, the court or arbitral tribunal can decide the applicable substantive law, as provided by institutional rules of the different domestic laws. ${ }^{34}$

\section{A particular note on maritime arbitration and applicable law}

\section{Party autonomy and maritime arbitration}

19. Party autonomy is divided between the following, as already explained: (i) procedural, where there is a choice between jurisdiction and ADR methods (Does arbitration [entrusted with laws and procedures] prevail? No maritime accidents have been resolved by arbitration. The procedural rule is the Brussels I Recast Regulation, with national civil procedure codes being applied subsidiarily [e.g. the declination of jurisdiction in Spain according to its civil procedure law]), (ii) in conflict of contract laws (referring automatically or not to the applicable law by the arbitrator) and (iii) material autonomy is composed of industry clauses provided by BIMCO, ${ }^{35}$ INTERTANKO $^{36}$ or INTERCARGO.${ }^{37}$

20. We lack mechanisms having a minimum legal certainty, so we must look in areas where there are unresolved issues. The CJEU provides interpretive guidelines on the Regulations. The Vienna Convention of the Law of Treaties of 1969 also contains interpretation guidelines for international instruments. We have a sum of very different regulatory elements that are difficult to reconcile with one another. When do we apply the lex fori? We can choose among the 'law of the siege of the institution' (French Law since the International Chamber of Commerce [ICC] headquarters are in Paris), the lex situs or a mixed system.

21. Which rules and procedural autonomy of the parties must be addressed? The contract can be governed by the lex mercatoria or the UNIDROIT Principles, ${ }^{38}$ for instance. In the United Kingdom (as well as in other common law jurisdictions such as the United States), the lex mercatoria may constitute

${ }_{33}$ H. Muir WatT, "Party autonomy", in J. BASEdow et al. (eds.), Encyclopedia of Private International Law, Edward Elgar Publishing Ltd., 2017, pp. 1336-1341, at pp. 1337-1338.

34 For instance, according to Articles 28(1) and (2) of The United Nations Commission on International Trade Law (UNCITRAL) Model Law on International Commercial Arbitration adopted on 21 June 1985, and recognised in Resolution No. 40/72 by the 112th plenary meeting of the UN General Assembly on 11 December 1985 (UN document A/40/17), as amended by the bill approved in the UN General Assembly in Resolution No. 61/33 from 18 December 2006 (UN Document A/RES/61/33).

35 Baltic and International Maritime Council (BIMCO).

36 Independent Tanker Owners Association (INTERTANKO).

37 International Association of Dry Cargo Ship owners (INTERCARGO).

38 UNIDROIT Principles of International Commercial Contracts (1994, 2004, 2010, and 2016 eds) drafted by the International Institute for the Unification of Private Law (UNIDROIT), an independent intergovernmental organisation. 
a selection of law. For the European continental law, it does not constitute a State law. The Rome I Regulation ${ }^{39}$ follows this, since it involves the choice of State law, although in the Inter-American Convention on the Law Applicable to International Contracts (known as the Mexico Convention) signed in 1994, the possibility of a contract without State law was agreed to, allowing the choice of the lex mercatoria. Article 7 states, 'The contract shall be governed by the law chosen by the parties.' However, this Convention is only in force in Mexico and Venezuela.

\section{Determination of the applicable law by the arbitral tribunal}

22. First, it is necessary to reflect on the margin of discretion available to arbitrators in the process of determining the law applicable to the substance of the dispute or the dispute submitted to such arbitration. Second, the degree of discretion to be taken by the arbitral tribunal in respect of the conventional provisions incorporated into the contract in question or imperatively applicable thereto should be determined. ${ }^{40}$

23. In this area of study, English doctrine and jurisprudence has delineated four major problems, with the most conflicting aspects needing to be resolved in relation to the determination of the applicable law in the context of a maritime arbitration process: determining 'the law of the agreement to arbitrate, the law of the arbitral proceedings, the law of the subject matter under dispute, and the conflict of laws rules applicable to the above'. ${ }^{41}$

24. The parties can select, within the framework of the arbitration agreement, the law that must govern the contract (governing law), either directly or well inferred indicatively through the normative elements present in the contract in question. ${ }^{42}$ The practice demonstrates the frequent use of floating choice of law clauses, which allow the parties (or one of them, or the arbitrator him or herself) to select in a discretionary manner the law applicable to the eventual controversy. ${ }^{43}$

25. The law applicable to a maritime arbitration process under the discretion of the arbitrator, not the substantial law of the case, as indicated by both doctrine and common law jurisprudence, ${ }^{44}$ should be defined according to the law of the agreement to arbitrate, the law of the arbitral proceedings, the law of the subject matter under dispute and the conflict of laws rules applicable to the above. ${ }^{45}$ The arbitrability of the dispute must be appreciated to ensure the subsequent execution of the award. Nevertheless, practice shows the frequent use of floating choice of law clauses ${ }^{46}$ that allow one or either parties, or even the arbitrator, to select on a discretionary basis the law applicable to any controversy. ${ }^{47}$

26. In the absence of an express determination by the parties, the presence of an arbitration clause operates as an indicative criterion for the existence of an implied choice of applicable law in favour of

39 Regulation (EC) No 593/2008 of the European Parliament and of the Council of 17 June 2008 on the law applicable to contractual obligations (Rome I). The Rome I Regulation (EU Regulation 593/2008) came into force on 17 December 2009 , and is applicable to all EU Member States except Denmark.

40 A widely held opinion on maritime doctrine is reflected in R. JAMBU-MerLIN's reflection in "L'Arbitrage Maritime", VV.AA.' in Etudes Offertes à Renè Rodière, Paris, Dalloz, 1981, pp. 401 et seq., where he states, 'L'arbitre, même lorsqu'il n'est pas amiable compositeur, même s'il doit respecter le droit, peut l'adapter avec la connivence des parties.'

${ }^{41}$ W. Tetley and R.C. Wilkins, International Conflict of Laws: Common, Civil, and Maritime, International Shipping Publications, 1994, pp. 385-423 (hereafter "TetLey \& WilKIns"); vid., ad ex., L. Collins, Essays in International Litigation and the Conflict of Laws, Oxford University Press, 1994 (hereafter "Coluins").

42 The principle of party autonomy in the context of carriage of goods by sea has been analysed by the doctrine in order to determine the applicable law, vid. ad ex., D. C. JACKSON, Enforcement of Maritime Claims, Informa Law from Routledge, 2013.

43 M. N. Howard, "Floating Choice of Law Clauses" Lloyd's Maritime \& Commercial Law Quarterly, 1995, pp. 1 et seq (hereafter "HowARD").

44 The arbitration clause provides for the substantive governing law while the Lex Arbitri guides the arbitration process.

45 TetLey \& Wilkins (note 41), pp. 385-423; Collins (note 41).

46 A. Briggs, "The Validity of 'Floating' Choice of Law and Jurisdiction Clauses", Lloyd's Maritime and Commercial Law Quarterly, no. 4, 1986, p. 508.

47 Howard (note 43), pp. 1 et seq. 
the place of arbitration. The parties assume that the arbitrators shall apply the law more familiar or close to their knowledge ${ }^{48}$ The place chosen in the contract for arbitration may be decisive in establishing the law applicable thereto, as well as any dispute arising. ${ }^{49}$ When determining the applicable law, the doctrine distinguishes among theories of localisation, delocalisation, or denationalisation of international arbitration. Tetley ${ }^{50}$ highlights three normative frameworks to analyse in relation to the frequency of disputes regarding the determination of the law applicable to such arbitration proceedings: a) 'standard charter party forms', b) international conventions and c) national laws.

\section{Direct actions and the compulsoriness for third party claimants of a dispute resolution and choice of law clauses in an insurance contract}

\section{Extra-European Union proceedings}

27. The English Court of Appeal's case Yusuf Çepnioğl$u^{51}$ involving non-EU actions follows the intra-EU Front Comor ${ }^{52}$ (where an arbitral tribunal awarded equitable damages following the breach of an exclusive London arbitration agreement) and the Gazprom $^{53}$ judgments (where a Lithuanian court enforced an anti-suit injunction rendered by Swedish arbitrators' following the breach of a Swedish arbitration clause). The case serves as an example concerning cargo claims involving an insurance policy containing an arbitration and applicable law clause solved by an EU Member State court involving a non-EU country.

28. The Yusuf Çepnioğlu vessel became a total loss after casting its cargo into the Ionian Sea after it ran aground on the coast of Mykonos. Turkish charterers, in breach of the London arbitration clause and by means of Turkish law, claimed direct compensation from the Luxembourg-based P\&I Club that insured the Turkish ship owner's vessel. The English Court of Appeal dismissed the appeal against the previous decision ${ }^{54}$ while issuing an anti-suit injunction to restrain the charterers from taking action in Turkey against the P\&I Club (thus, in this case the proceedings did not take place in the courts of another EU Member State).

29. The English Court of Appeal held that there was a breach of contract by the charterers because they were bound by the insurance contract between the ship owners and the P\&I Club. Having foreign provisions alienates the purpose of having an arbitration clause since it is part of the rights acquired by the insurer from the insured through subrogation.

30. A charterers' claim has to be characterised in order to know whether it was a contractual. The Court of Appeal decided to characterise the claims as tortious, making the victim a third party to the insurance contract. The victim claimed a lack of benefits for him from such contract, agreeing with the insurer's intentions, rather than adopting the charterer's point of view and considering the insurer a third party liable in tort as a consequence of another's wrongdoing. Whereas, under Article 13(1) of the Brussels I Recast Regulation, 'in respect of liability insurance, the insurer may also, if the law of

48 R. Asariotis, "Contracts for the Carriage of Goods by Sea and Conflict of Laws: Some Questions regarding the Contracts (Applicable Law) Act 1990”, Journal of Maritime Law and Commerce, no. 26, 1995, p. 293.

49 J. M. Ruiz Soroa, S. Zabaleta Sarasua and M. González Rodríguez, Manual de Derecho del Transporte Marítimo, Instituto Vasco de Administración Pública, 2 Vitoria-Gasteiz, 1989, p. 130.

50 W. TetLey, "Charterparties and choice of law", Il Diritto marittimo, vol. 94, no. II, 1992, pp. 1146-1189.

51 Shipowners' Mutual Protection and Indemnity Association (Luxembourg) v Containerships Denizcilik Nakliyat VE Ticaret AS (The Yusuf Çepnioğlu) [2016] EWCA Civ 3861 Lloyd's Rep. 641.

52 West Tankers Inc v Allianz SpA (formerly Riunione Adriatica Sicurta) [2012] EWHC 854 (Comm).

53 Judgment of the CJEU of 13 May 2015, C-536/13, Gazprom OAO v Lietuvos Respublika [2015] EU:C:2015:316, 1 Lloyd's Rep. 610.

54 [2015] EWHC 258 (Comm); [2015] 1 Lloyd's Rep. 567. 
the court permits it, be joined in proceedings which the injured party has brought against the insured'. The second view was justified in another case pending on appeal under Supreme Court's permission. ${ }^{55}$

31. There could be a transfer of the rights of the insured against its liability insurer to the party who has suffered the loss as a result of the insured's breach of contract or tort in case of insolvency ${ }^{56}$ or winding up of the insured, according to the 1930 English Third Parties (Rights Against Insurers Act), which has been replaced by the 2010 Act since 1 August 2016. In Briggs's opinion, the Court of Appeal wrongly concluded that the charterers were bound by the arbitration agreement characterising the charterer's contractual claim under the 2012 Turkish Insurance Contract Law, with the insurance contract as the cause of action including the dispute resolution clause. According to the common law rules of PIL, the victim of the tort (ie the charterers), who were a party to the contract of insurance, could choose to claim in tort against third parties to such tort (i.e. the insurers), making them personally liable by the principle of lex delicti commissii.

32. According to Article 4(1) and (2) of the Rome II Regulation on the law applicable to noncontractual obligations, the common habitual domicile was in Turkey, although the accident took place in Greece:

'The law applicable to a non-contractual obligation arising out of a tort/delict shall be the law of the country in which the damage occurs irrespective of the country in which the event giving rise to the damage occurred and irrespective of the country or countries in which the indirect consequences of that event occur. However, where the person claimed to be liable and the person sustaining damage both have their habitual residence in the same country at the time when the damage occurs, the law of that country shall apply.'

33. Liability was determined according to the scope of the law applicable, as stated in Article 15 of the Rome II Regulation. The issue at stake was that the claimant never agreed and bound itself to arbitrate the claim filed at court. Briggs disagrees with the outcome of The Yusuf Çepnioğlu decision. In the present case, providing a third party with a direct claim against the other party's insurer does not necessitate assuming that the beneficiary of the statutory right is subject to a dispute resolution clause that he did not negotiate. The issue of common law principles of characterisation for the purpose of choice of law in the context of the Rome I and Rome II Regulations will be the subject of future judicial scrutiny. ${ }^{57}$

34. Assuming that the victim would be obliged to sue according to the dispute resolution clause of the insurance contract, a further twist occurs in characterising such a clause as contractual or notcontractual, since the Rome I Regulation in its Article 1(2)(e) (unlike the Rome II Regulation) contains an exception for 'arbitration agreements and agreements on the choice of court'. A contractual obligation would be subject to the common law choice of law rules considering the overriding effect of the Brussels I Recast Regulation. A non-contractual obligation would be determined according to Article 4 concerning the law applicable to non-contractual obligations arising out of tort or delict, extending the measures that a court can take to prevent or terminate injury or damage under Article 15(d) of the Rome II Regulation.

35. It should be pointed out that, according to Article 18 of the Rome II Regulation, the party that has suffered the damage can choose to bring a direct action against the insurer of the person liable to provide compensation if the law applicable to the non-contractual obligation or the law applicable to

55 Hoteles Piñero Canarias SL v Keefe [2015] EWCA Civ 598; [2016] Lloyd's Rep. IR 94; [2016] 1 WLR 905.

56 In Stichting Shell Pensioenfonds v Krysxi [2015] AC 616, [32]; [2014] UKPC 41, the Dutch company Shell invested funds in a British Virgin Islands company, part of Bernard Madoff's businesses. The respondent liquidator's appeal at the British Virgin Islands-Eastern Caribbean Court of Appeal was dismissed since the British Virgin Islands' company became insolvent, and it would be wound up under the law of such jurisdiction, confirming that there was no basis to complain about the anti-suit injunction ordered by the court to prevent Shell from commencing proceedings in the Netherlands; A. BRIGGS, "Judicial Assistance Still in Need of Judicial Assistance", Lloyd's Maritime \& Commercial Law Quarterly, no. 2, 2015, pp. 179-193.

57 A. Briggs, "Direct Actions and Arbitration: All at Sea", Lloyd's Maritime \& Commercial Law Quarterly, no. 3, 2016, pp. 327-331. 
the insurance contract so provides. A choice of law between the parties to submit their non-contractual obligations before the harmful event occurs shall not prejudice the rights of third parties under Article 14(1) of the Rome II Regulation.

36. The CJEU's case law has interpreted such choice of law agreement as entitling the victim to bring a direct action by reference to one of those laws, even in the case of such action being precluded by the other law. ${ }^{58}$ This case deals with an action brought outside the EU, and Article 18 of the Rome II Regulation would be unlikely to be applicable. Assuming that English law would be applicable to the anti-suit claim, it is arguable whether 'the foreign claimant behaved unconscionably or not in light of the circumstance that an English claimant in an identical position would have the right to invoke a direct action under the law applicable to the tort committed against him.' It would be almost certain that Turkish Law would be applicable according to Article 4 of the Rome II Regulation, even if the law applicable to the insurance policy would prohibit it.

37. A clear and express choice of the arbitration place must be taken according to the Rome I Regulation, but it is uncertain whether or not the $\mathrm{B} / \mathrm{L}$ choice of law is binding for the $\mathrm{B} / \mathrm{L}$ holder. Article 27 (review clause) of the Rome I Regulation states that certain issues should have been reviewed by 2010 ('a report on the question of the effectiveness of an assignment or subrogation of a claim against third parties and the priority of the assigned or subrogated claim over a right of another person'), and by 2013 ('the law applicable to insurance contracts and an assessment of the impact of the provisions to be introduced, if any; and an evaluation on the application of Article 6, in particular as regards the coherence of EU law in the field of consumer protection'). According to Article 19 (subrogation):

'Where a person (the creditor) has a non-contractual claim upon another (the debtor [or insured]), and a third person has a duty to satisfy the creditor, or has in fact satisfied the creditor (the insured) in discharge of that duty, the law which governs the third person's duty to satisfy the creditor [the law applicable to the insurance contract] shall determine whether, and the extent to which, the third person is entitled to exercise against the debtor the rights which the creditor [the insured] had against the debtor under the law governing their relationship.

38. Dickinson points out that the absence of any reference to the Rome I and Rome II Regulations in this case 'should lead lawyers and judges in future cases to treat the outcome and reasoning with distinct caution' ${ }^{59}$ Brigg's ${ }^{60}$ and Dickinson' ${ }^{61}$ opinions (concerning the beneficiary of a statutory right who is not subject to a dispute resolution clause of the insurance contract that he never negotiated) are supported by the CJEU's Assens Havn case ${ }^{62}$ in the EU context. The judgment, where domestic law was applicable even though the P\&I Club's insurance policy provided for English law, is introduced in the next subsection.

\section{Intra-European Union proceedings}

39. Following the Yusuf Çepnioğlu judgment concerning extra-EU actions in breach of an arbitration clause, a different scenario is illustrated by the CJEU case law involving intra-EU actions where the party that suffered damage was not bound by the insurance policy and the jurisdiction and applicable law clauses contained therein. A Swedish company, Skåne Entreprenad Services AB (the charterers), chartered tugs and lighters in connection with the transportation of sugar beet between the Danish ports of Naksov and Assens in 2007. The Port of Assens suffered damages and brought a direct action against

\footnotetext{
58 Judgment of theCJEU of 9 September 2015, C-240/14, Eleonore Prüller-Frey v Norbert Brodnig and Axa Versicherung $A G$ [2015], ECLI:EU:C:2015:567, WLR (D) 377 at [44].

59 A. J. Dickinson, "The Right to Rome? The Law Applicable to Direct Claims against Insurers and Anti-Suit Injunctions (the Yusuf Cepnioglu)", 132 Law Quarterly Review, 2016, pp. 536-541.

60 Vid. A. BrigGs (note 36), pp. 327-331.

${ }^{61}$ Vid. A. J. Dickinson (note 38), pp. 536-541.

62 Judgment of the CJEU of 13 July 2017, C-368/16, Assens Havn v Navigators Management (UK) Ltd [2017], ECLI:EU:C:2017:546.
} 
the P\&I insurers at the Sø-og Handelsret (Maritime and Commercial Court of Denmark) seeking compensation, since the charterers of the tug went into liquidation.

40. The court dismissed the action since the P\&I policy provided for the exclusive jurisdiction of the High Court of England and Wales and governance by the law of England and Wales (under the terms of the 1906 English Marine Insurance Act). The Port of Assens appealed the decision to the Højesteret (the Supreme Court of Denmark), which stayed proceedings and referred the question of whether a party bringing an action against an insurer is bound by the exclusive jurisdiction agreement of the insurance policy to the CJEU. ${ }^{63}$

41. According to Articles 8 to 10 of the Brussels I Regulation the insurer may be sued in the place where the harmful event occurred or where the victim is domiciled. Article 13(5) makes derogation from a general jurisdiction agreement possible since Article 14(2)(a) includes insurance contracts covering the liability arising out of the use or operation of the ships. Without referring to Articles 13(5) and 14(2)(a) of the Regulation, the CJEU restricted derogation from the jurisdictional rules concerning insurance by applying Article 11(2) of the Brussels I Regulation, which allows direct actions by the injured party against the insurer (when domestic law provides for it) in order to protect the economically and legally weaker party. However, Article 23(5) states that agreements or provisions conferring jurisdiction shall have no legal force if they are contrary to Article 13 of the Regulation. The Port of Assens never agreed to the insurance policy, and the text of Brussels I Recast Regulation maintains similar wording to the Brussels I Regulation. It remains unclear whether the exclusion of arbitration in the Brussels I Recast Regulation would lead to a different decision. ${ }^{64}$

\section{Limitations on choice of forum and arbitration agreemements based on the the identity of the shipping carrier}

\section{Introduction}

42. The importance of clearly identifying the contractual carrier is paramount to recover any damages, delay, or loss affecting the cargo by any claimant. It will be equally difficult enforcing a jurisdiction or arbitration clause included in a $\mathrm{B} / \mathrm{L}$ if the parties are not clearly defined in the contract for the carrige of goods by sea constituting a limitation on party autonomy. The $\mathrm{B} / \mathrm{L}$ may serve as evidence of the contract of carriage with the charterer or the shipowner, but this evidence varies depending on the law of the forum where the shipper brings a cargo claim. The $\mathrm{B} / \mathrm{L}$ signatory party may be sued in contract unless a Demise or 'Identity of the Carrier' Clause is included.

43. A cargo claimant may sue the contractual carrier that issued the $\mathrm{B} / \mathrm{L}$ or the actual carrier, normally the charterer, in tort. ${ }^{65}$ The 'Demise Clause' normally allocates responsibility for $\mathrm{B} / \mathrm{L}$ liability to the shipowner instead of the charterer. Therefore, inclusion of the demise caluse in the $\mathrm{B} / \mathrm{L}$ is seems to be favourable to correctly identify the responsible party in cargo claims. However, Article III(8) of the Hague-Visby Rules ${ }^{66}$ are applicable to Demise Clauses in certain countries rendering void any term of a carriage contract, which purports to limit the obligation to a lower standard than the ones required

${ }^{63}$ T. Miller, C. Primikiris and B. CAmel, "The European Court of Justice-Assens Havn -v- Navigators Management (UK) Limited C-368/16", Shipping Case Diges, August 2017 edn.: <www.hilldickinson.com/insights/Articles/european-court-justice-assens-havn-v-navigators-management-uk-limited-c-36816> accessed 26 December 2017.

${ }^{64}$ J. O'KeefFe and C. Crane, "CJEU Ruling Exposes Liability Insurers to Direct Actions across the EU”, Knowledge Bank, Sector Insights, INCE \& Co, 7 September 2017: <www.incelaw.com/en/knowledge-bank/cjeu-ruling-exposes-liability-insurers-to-direct-actions-across-the-eu> accessed 26 December 2017.

65 K. SATORI, “The demise clause in Japan”, Lloyd's Maritime and Commercial Law Quarterly, 1998, pp. 489-498.

66 International Convention for the Unification of Certain Rules of Law Relating to Bills of Lading signed at Brussels on 25 August 1924 ('the Hague Rules') 51 Stat 223, vol. 120 LNTS, p. 155, amended by the Protocol to Amend the International Convention for the Unification of Certain Rules of Law Relating to Bills of Lading signed at Brussels on 23 February 1968 ('the Visby rules') vol. 1412 UNTS, p. 121, and the last Protocol amending the Hague-Visby Rules signed at Brussels on 21 December 1979 ('SDR Visby Protocol') vol. 1412 UNTS, p. 146. 
by the Rules.$^{67}$ In other words, the Demise Clause is not recognised in some jurisdictions, making the charterer liable when the contractual counterpart is intended to be the shipowner.

\section{General rules in defining responsibilities}

44. Indirect liability is established when the $\mathrm{B} / \mathrm{L}$ serves as evidence of a contract with the shipowner. The shipowner may bring an indemnity claim against the charterer for any monies paid to the shipper as the result of a claim based on charter party terms. Conversely, the charterer may bring an indemnity claim against the shipowner after disbursing compensation to the shipper if there has been a cargo claim under the terms of a head charter party. In other words, the charterer may bring actions against the shipowner under the head charter party if it had paid the shipper for a claim under the $\mathrm{B} / \mathrm{L}$.

45. Identifying the actual or contractual carrier may present practical difficulties. A $\mathrm{B} / \mathrm{L}$ is often signed by the charterer or his or her agent on behalf of the master, making the charterer liable in some jurisdictions. However, in some countries, a B/L may still provide evidence of a contract with the shipowner, depending on the wording in the signature box and the clauses on the back of the $\mathrm{B} / \mathrm{L}$. In many countries the carrier has to be the shipowner, although the charterer is always the carrier unless there is a specific agreement, for instance, stating that a concrete part of the voyage is being performed by a main charterer. Furthermore, the charterer and the shipowner may be the carrier in some States. ${ }^{68}$

\section{The identity of the charterer and the shipper under Scandinavian law}

46. In order to provide an analysis of how the shipping actors have a different legal characterisation the following clarifications are deemed necessary. The definition crosses boundaries between civil law and common law. In English or Spanish law, for instance, the charterer and shipper are treated as different actors. However, Danish and Scandinavian law have a unique method of deciding who the carrier is.

47. Under Scandinavian law, for example, according to sections 285, 286 and 287 of the Nordic Maritime Code (NMC), as in many countries, the carrier will be the charterer (S 321 NMC; 'the carrier is the person who, through a contract, charters out a ship to another', ie the charterer; S $324 \mathrm{NMC}$; if the charterer assigns his right according to a chartering agreement to someone else or sub-charters the ship, the charterer remains responsible for the performance of the contract). The carrier may not assign the chartering agreement without the consent of the charterer. If the charterer has consented, the liability of the carrier under the contract ceases. ${ }^{69}$

\section{Comparative case law on the limitations on dispute resolution agreements based on the identity of the carrier}

48. The following selected comparative examples have been chosen as examples of how the carrier is characterised in some European countries: England, Germany and Spanish. These examples show how the identification of the carrier may limit commencing proceedings in different fora. It is paramount to identify correctly the carrier.

\section{A) England}

49. According to English law, the shipowner is the proprietor of the vessel, as the shipowner

${ }^{67}$ Vid. C.H. Spurin, "Chapter V The liability of carriers to cargo owners", The Law of International Trade and Carriage of goods, Nationwide Mediation Academy for NADR UK Ltd., 2004, pp. 87-88.

68 Gard Services AS, “A Charterer's Involvement in Cargo Claims”, 164 Gard News Insight, 2001: <http://www.gard.no/ web/updates/content/53043/a-charterers-involvement-in-cargo-claims> accessed 29 January 2018.

${ }_{69}$ For more information concerning the liability of the charterer and the carrier in Scandinavian countries, vid., ad ex., A. Møllmann, Delivery of Goods Under Bills of Lading, Routledge, 2016, pp. 36-39; vid. L. Gorton, "The liability for freight", in U. Bernitz and J. Ramberg (eds.), Festskrift till Jan Ramberg, Juristförlaget, 1996, pp. 165-184. 
always owns it. For instance, in The Antares case,$^{70}$ a Demise Clause was present. The charterer was an agent of the shipowner and not the shipowner as the claimants had mistakenly thought based on the charterer's behaviour. The charterer did not mention that he was the charterer and not the shipowner, and the claimants sued the charterer. The charterer was released from any responsibility since two days after the one-year time-bar of the Hague-Visby Rules had passed. The charterer later informed the B/L holders - allegedly on purpose - that it was not the shipowner. This makes applying for an action in rem relevant. Choices are made based on an economic analysis of who is worth suing. The Identity of the Carrier Clause and the Demise Clause are relevant in order to sue to bring an action in time before is time-barred.

50. The identity of the carrier is clear when the claimant is the contractual counterparty. Nevertheless, difficulties may arise in sub-chartering scenarios. Where the claimant in a cargo claim is a charterer, its carrier is the party who chartered the ship for him or her. Where the claimant is not a charterer, then the identity of its carrier will appear on the logo heading of the $\mathrm{B} / \mathrm{L}$ covering the goods and the signature at the bottom of the $\mathrm{B} / \mathrm{L}$. In The Starsin ${ }^{71}$ the House of Lords held that the signature on the $\mathrm{B} / \mathrm{L}$ prevailed as evidence of the identity of the carrier for an express 'Identity of the Carrier' Clause contained on the reverse of the $\mathrm{B} / \mathrm{L}$. If the actual carrier is different from the legal carrier and there is no privity of contract between the shipper and the actual carrier, the claimant may sue the actual carrier that commits a tort or is in breach of its duties as a bailee in case of being able to prove it. When the shipowner is the actual carrier, it can rely on a dispute resolution clause when it endorses the $\mathrm{B} / \mathrm{L}$ as a head bailee to the shipper or in the case of sub-bailment on terms. ${ }^{72}$

\section{B) Spain}

51. An endorsee should be influenced by jurisdiction clauses to act in sensu stricto when transporting and carrying goods by sea; however, it is unclear and endorsee should accept such clauses under Spanish law. The Spanish Maritime Navigation Act (SMNA) ${ }^{73}$ supports the transmission of a variety of rights and obligations but does mention party autonomy. Currently, the term 'freedom of will' is often abused to distort acceptance of the contract clauses already accepted by parties. The identification of the reponsible party under Spanish law is explained through the judgment No 1098/2008 of the Spanish Supreme Court on 4 December 2008.

52. In this case, the underwriters Aegon Unión Aseguradora, SA de Seguros y Reaseguros claimed for cargo damage during a transport of goods from China to Spain by the Inditex group (Zara). The value amounted to EUR 125,000. Aegon's claim was successful in its claim against Birkart (Far East) Ltd, the freight forwarder, and the AP Møller Group's Maersk Line, the carriers. Maersk España SA, the ship agents, appealed the decision. The basis of the claim was found in Article 586 of the Spanish Code of Commerce, ${ }^{74}$ according to which the ship agent is considered the carrier of goods in Spain, since the new SAMN was not in force. Article 586 of the Spanish Code of Commerce states:

'The shipowner and the shipping agent shall be held civilly liable for the actions of the Master and the obligations contracted by him to repair, fit out and stock the ship, provided that the creditor justifies that the moneys claimed were invested to the benefit of the former.

70 Kenya Railways $v$ Antares Co Ltd (The Antares) [1987] 1 Lloyd's Rep 424.

71 Homburg Houtimport BV v Agrosin Private Ltd (The Starsin) [2003] 1 Lloyd's Rep 571.

72 Vid. ad ex. J. Cooke, T. Young, M. Ashcroft, A. Taylor, J. Kimball, D. Martowski, L. Lambert and M. Sturley, Voyage charters (Informa Law from Routledge 2014) at [85-61 and [85-71]; Y. Yvonne, C. Debattista, F. Lorenzon, A. Serdy, H. Staniland and M. N. Tsimplis, The Rotterdam Rules: A Practical Annotation, Informa Law from Routledge, 2009, at [62-07]; R. Aikens, R. Lord and M. Bools, Bills of lading, Informa Law from Routledge, 2015, at chapter 7.

73 Articles 251 and 468 of the Spanish Act 14/2014 of 24 July 2013, on maritime navigation (Official State Gazette No 125 of 26 May 2015).

74 The repealed Articles on Spanish private maritime law are contained in Book III of the Spanish Code of Commerce, as modified by supplementary laws, approved by Royal Decree of 22 August 1885 (Gazette numbers 298 to 328, from 16 October to 24 November 1885). 
A shipping agent is defined to be the person in charge of stocking or representing the ship in the port where the ship is.

"AP Moller provided a B/L in which it was not named as such but as the AP Møller group, causing confusion as they belong to the same group. The combined $\mathrm{B} / \mathrm{L}$ provided by the AP Moller group prevailed over the separate copies of the $\mathrm{B} / \mathrm{L}$, which clarified that, in case of non-compulsory application of the Hague-Visby Rules (China has not joined them), the Hague Rules should be applicable, limiting Maersk España's liability to GBP 22,500." 75

53. According to Article 145(1) The SAMN, the shipowner is defined as the 'party that, whether or not it is the owner, has the possession of a ship or vessel, directly, or through its servants, and uses it for navigation in its own name and under its responsibility'. However, Article 145(2) defined the ship operator or shipping company as 'the natural or legal person that, using own or third party merchant ships, carries out the operation thereof, even when that is not its main activity, under any mode permitted in international practice'.

54. The definition of the former Article 586 of the Spanish Code of Commerce and Article 3 of the Law on Maritime Transportation ${ }^{76}$ stated that the ship agent was liable to indemnify cargo recipients for any loss, damage or delay in the delivery of the cargo. This was due to the linkage between the ship agent and the ship operator. However, this contrasts with the responsibility of the ship agent in the case of the ship operator or the shipowner being liable for fault or whenever the ship agent does not sign the $\mathrm{B} / \mathrm{L}$ specifying that is doing so on behalf of the shipowner, the ship operator or the charterer concerning cargo claims. When the agent assumes other functions as a freight forwarder or takes care of port operations, it will be also liable.

\section{C) Germany}

55. The basis for identifying the responsible party followed by the German Supreme Court is presented in a case ${ }^{77}$ similar to The Starsin. The court held invalid an Identity of the Carrier Clause referring to the shipowner in a $\mathrm{B} / \mathrm{L}$ that named the charterer as the carrier on its face. The jurisdiction clause provided for the principal place of business of the carrier. The cargo interests sued the shipowner in German courts, which found they did not have competency to hear the case because the individual agreement, by naming the charterers on the face of the $\mathrm{B} / \mathrm{L}$, prevailed over the Identity of the Carrier Clause set out in the general terms and conditions of the $\mathrm{B} / \mathrm{L}$ under German law.

56. English law and jurisdiction were applicable to the case despite the fact that (current) Article 25 of the Brussels I Recast Regulation, referring to trade usages and customs of the sector, was applicable to the individual agreement and English law was applicable to the rest of the contract, including the jurisdiction clause. ${ }^{78}$

\section{Conclusions}

57. As shown above different practices are in place around the world. A summary of the findings of the previous analysis shows that the bundle of bilateral relations underlying the contract of affreightment constitutes a pattern for material party autonomy.

75 J. Echebarria Fernández, “Action Research and Efficient Maritime Transport Contract Negotiation”, in P. A. Nielsen, P. K. Schmidt and K. D. Weber (eds.), Erhversretlige emner: Juridisk Institut CBS, Djøf / Jurist- og Økonomforbundet, 2015, pp. 49-63.

76 Spanish Maritime Transport Act of 22 December 1949 (Official State Gazette No 358 of 24 December 2015).

77 BGH 15 February 2007 NJW 2007, 2036.

78 Gard Services AS, "Identity of Carrier and Jurisdiction Clauses in Germany", 186 Gard News Insight, 2007: < http:// www.gard.no/web/updates/content/53413/identity-of-carrier-and-jurisdiction-clauses-in-germany> accessed 29 January 2018. 
58. Firstly, there is a plurality of answers when the parties have intended to set the material conditions of transport, including ancillary operations. It is impossible to disconnect one thing from the other: A legal and contractual operator wants to have a regulatory framework that provides a reasonable expectation of the place and applicable law in case of dispute. The current EU legal framework provides a large scope of party autonomy in conflict of contract laws, but this 'conflictual' autonomy implies a non-harmonised model.

59. Secondly, there is no true model of party autonomy in conflict of contract laws when the conflictual choice is agreed to by the parties or imposed by one of them through a standardised-type contract. For instance, the "law of the forms" promises more than what it can fulfil. The templates developed by large private organisations such as BIMCO, INTERTANKO or INTERCARGO provide no legal certainty in material terms.

60. Thirdly, it shall be noted that where available, anti-suit injunctions are effective in a non-EU context and when the English courts are sought by the parties to restrain proceedings in a foreign nonEU Member State court and to a certain extent to EU Member State courts are found in breach of an arbitration agreement as in the Gazprom case. The third party compulsoriness to the choice of law and arbitration clause in the Yusuf Çepnioğlu case issued by English courts contrasts with the opposite result drawn up by the CJEU's Assens Havn case.

61. Fourthly, the importance of clearly identifying the contractual carrier is paramount to recover any damages, delay, or loss affecting the cargo by any claimant. Problems arise in sub-chartering scenarios. In England the signature of the B/L prevails over any Identity of the Carrier Clause. However, when the actual carrier differs from the legal carrier the shipper may sue the first in tort without any obligation to be abided by a dispute resolution or choice of law agreement. A shipowner that endorses a $\mathrm{B} / \mathrm{L}$ acting as a head bailee may me sued by a shipper in bailment or in sub-bailment on terms when the shipowner becomes a sub-bailee of a head bailee charterer that receives the goods from the bailor (the shipper). The limitations and defences of the Hague-Visby Rules are available to the bailee or subbailee including the possibility of relying on the dispute resolution clause when a protective Paramount or Himalaya Clause for the limitation of liability explicitly provide for it but not when the shipowner or charterer are in tort since there is no privity of contract between the tortfeasor and the shipper.

62. Fifthly, Spain's SMNA sets out restrictive conditions for the endorsement of dispute resolution clauses when applicable but it shall be borne in mind that the more liberal Article 25 of the Brussels I Recast Regulation operates when there is a submission agreement in favour of an EU Member State court. The ship agent was legally responsible for any damage to the cargo as the ship operator under the outdated Spanish Code of Commerce and the Spanish Law on Maritime Transportation when the B/L was signed on behalf of the ship owner. The SMNA does not replicate the former applicable legal regime and entrusts different responsibilities to the shipowner, the ship operator and the ship agents.

63. Finally, some jurisdictions such as Germany do not recognise the validity of the Identity of the Carrier Clauses as in the Starsin English case, leading to the application of foreign law under Article 25 of the Brussels I Recast Regulation. The German Supreme Court's judgment recognised the jurisdiction and choice of law clause that pointed out to the carrier's principal place of business. The key issue at stake was the validity of the Identity of the Carrier Clause that would lead to the application of German law. However, naming the charterers as carriers in the $\mathrm{B} / \mathrm{L}$ constituted an individual agreement prevailing over the Identity of the Carrier Clause and thus leading to a valid submission to English law and jurisdiction under Article 23 of the Brussels I Regulation in relation to maritime trade usages and customs. 